\title{
PENERAPAN MEDIA PEMBELAJARAN ANIMASI DAN STRATEGI PEMBELAJARAN AKTIF THE POWER OF TWO TERHADAP HOTS (HIGHER ORDER THINKING SKILLS) PADA PEMBELAJARAN MA- TEMATIKA KELAS IV SEKOLAH DASAR
}

\author{
Penulis \\ : Windia Alfiani \\ Institusi \\ : Magister Teknologi Pendidikan Universitas Muhammadiyah Jakarta \\ Email Korespondensi ： windiaalfiany@gmail.com \\ DOI \\ : https://doi.org/10.53947/perspekt.v1i1.6
}

Kata Kunci :

Strategi Pembelajaran aktif

The Power Of Two

Media Animasi

Kemampuan Hots

Matematika Siswa Sd

Keywords:

Active Learning Strategy

The Power Of Two

Animation Media

Hots Ability

Elementary Student Mathematics

\begin{abstract}
Abstrak
Penulisan artikel ini bertujuan untuk mendesain pembelajaran sehingga diperoleh rancangan pembelajaran yang aktif, inovatif, kreatif, mandiri, serta menyenangkan sehingga pesan pembelajaran dapat tersampaikan dengan baik. Rendahnya kemampuan siswa dalam berpikir tingkat tinggi perlu ditingkatkan dengan memberikan latihan soal-soal yang berbeda dengan contoh yang telah diberikan oleh guru. Salah satunya dengan menggunakan soal Higher Order Thinking Skills (HOTS) yang merupakan soal tingkatan yang kompleks. Ketika siswa dihadapkan pada soal HOTS maka akan menghasilkan berbagai cara penyelesaian dari soal tersebut. Di dalam kelas khususnya pembelajaran matematika SD terlihat proses belajar yang kurang efektif. Guru dari awal pembelajaran memulai kegiatan belajar dengan berdoa, kemudian mengabsen kehadiran siswa, menjelaskan dengan monoton dan nyaris tak menggunakan alat yang dapat memudahkan siswa dalam belajar. Dengan memperhatikan masalah di atas, sudah seharusnya dalam proses pembelajaran matematika guru perlu melakukan suatu perubahan atau inovasi yang dapat menggairahkan siswa dalam belajar. Diperlukan alternatif strategi pembelajaran yang mampu membangkitan semangat, motivasi, kreatif dalam mengikuti pembelajaran. Salah satu cara yang dapat dilakukan melalui penerapan strategi pembelajaran the power of two, juga mendesain sebuah media pembelajaran animasi yang menarik dengan Macromedia Flash.
\end{abstract}

\footnotetext{
Abstract

Writing this article aims to design learning to be active, innovative, creative, independent, and fun for students. The low thinking ability of students needs to be improved by giving practice questions that are different from the examples given previously by the teacher. One of them is using Higher Order Thinking Skills (HOTS) questions which are complex level questions. When students are faced with HOTS questions, they will produce various ways of solving problems. In the classroom, especially elementary mathematics learning, the learning process is seen as less effective. From the beginning of learning, the teacher starts learning activities by praying, then doing student attendance, explaining monotonously, and not using assistive devices. By paying attention to the problems above, in learning mathematics, teachers need to make innovations that can excite
} 
students in learning. One of the ways to do this is by implementing a power of two learning strategies and designing engaging animated learning media with Macromedia Flash.

\section{PENDAHULUAN}

Dalam kehidupan sehari-hari pada masa kini dan masa mendatang, diperlukan upaya keras untuk menjadikan matematika sebagai sesuatu yang penting. Oleh karenanya matematika harus dipelajari peserta didik karena kegunaanya sangat nyata dalam kehidupan sehari-hari. Ketika siswa diberikan soal matematika permasalahan yang membuat berpikir siswa cenderung sama dengan contoh diberi guru. Tetapi, saat siswa diberi soal agak sedikit berbeda dengan contoh yang diberikan, siswa merasa kesulitan menyelesaikan soal itu. Kondisi seperti ini membuat siswa dituntut menerima sesuatu yang dianggap penting oleh guru. Siswa masih mempunyai kemampuan berpikir tingkat tinggi. Potensi ini belum dikembangkan sehingga kemampuan berpikir yang dimiliki siswa dalam tes matematika tergolong masih rendah.

Salah satu permasalahan pendidikan di Indonesia adalah rendahnya kemampuan berpikir tingkat tinggi siswa. Kondisi ini terlihat dari rendahnya posisi Indonesia di antara negara-negara Organization for Economic Cooperation and Development (OECD) pada hasil penelitian Programme International for Student Assessment (PISA). PISA merupakan salah satu studi internasional yang mengukur kemampuan pengetahuan dan keterampilan dalam tiga domain kognitif, yaitu membaca, matematika, dan sains peserta didik.

Studi internasional yang mengukur kemampuan kognitif peserta didik yang lain adalah TIMSS (Trends in Mathematics and Science Study). Studi ini bertujuan untuk mengukur kemampuan siswa pada bidang matematika dan sains di kelas empat SD dan delapan SMP. Soal TIMSS mengukur tiga aspek kemampuan kognitif yaitu, knowing (pemahaman), applying (penerapan) dan analysing (penalaran). Dari ketiga aspek tersebut, aspek pemahaman dan penerapan termasuk dalam kemampuan berpikir dasar atau kemampuan berpikir tingkat rendah (Low Order Tthinking). Sedangkan aspek penalaran termasuk dalam kemampuan berpikir tingkat tinggi (High Order Thinking) (Lesmana, 2016: 143).

Posisi Indonesia pada hasil penelitian PISA 2015 menempati peringkat 62 dari 70 negara untuk aspek literasi sains (OECD, 2016). Berdasarkan hasil survey PISA tahun 2012 Indonesia hanya sedikit lebih baik dari Peru yang berada di ranking terbawah. Ratarata skor matematika anak-anak Indonesia 375. Indonesia hanya menduduki ranking 64 dari 65 negara dengan rata-rata skor 375 , sementara rata-rata skor matematika internasional adalah 500 (OECD, 2014).

Pesatnya perkembangan pengetahuan dan teknologi pada abad 21 tidak serta merta meningkatkan ranking siswa Indonesia pada PISA dan TIMSS. Tercatat pada tahun 2015 Indonesia menduduki peringkat ke-64 dari 72 negara yang berpatisipasi pada PISA, dan menduduki peringkat ke-45 dari 48 negara yang berpatisipasi pada TIMSS (Nugroho, 2018:11). Rendahnya hasil tersebut 
mengharuskan dunia pendidikan Indonesia mempersiapkan diri untuk menghadapi pesatnya perkembangan pengetahuan dan teknologi abad 21.

Rendahnya kemampuan siswa dalam berpikir tingkat tinggi perlu diperbaiki dengan memberikan latihan soal-soal yang berbeda dengan contoh yang telah diberikan oleh guru. Salah satunya dengan menggunakan soal Higher Order Thinking Skills (HOTS) yang merupakan soal tingkatan yang kompleks. Ketika siswa dihadapkan pada soal HOTS maka akan menghasilkan berbagai cara penyelesaian dari soal tersebut.

\section{PEMBAHASAN}

Penerapan pembelajaran HOTS pada siswa kelas IV Sekolah Dasar sudah dapat diterapkan dikarenakan tingkat berpikir siswa sudah matang. Hal ini dapat dilihat dari perkembangan berpikir siswa $\mathrm{SD} / \mathrm{MI}$, guru perlu mengetahui benar sifat-sifat dan karakteristik siswa agar dapat memberikan pembinaan dengan baik dan tepat. Perubahan-perubahan yang terjadi pada anak usia 6-12 tahun terkait dengan perkembangan kognitif Jean Piaget seperti dikutip Syaodih \& Sumantri (2006: 49) dan Arini (2017: 146) terjadi dalam tiga tahap. Pertama, melukiskan tentang tahapan operasi konkrit. Kedua, berbagai pendekatan yang difokuskan pada proses. informasi terhadap peningkatan memori (ingatan) dan komunikasi serta pemecahan masalah. Terakhir, ketiga, ukuran inteligensi untuk dapat memperkirakan kemampuan akademik.

Pada fase operasi konkret anak telah sanggup untuk memahami banyak konsep matematika, ilmu pengetahuan alam, dan ilmu-ilmu sosial secara intuitif dan konkrit. Senada dengan hal tersebut Novikasari dalam Arini (2017: 146) menyatakan bahwa perkembangan intelektual sangat substansial, karena sifat egosentrik, anak menjadi lebih bersifat logis. Dari perkembangan kognitif tersebut sekolah harus mampu mengembangkan kemampuan berpikir anak sehingga akhirnya dapat menunjukkan kualitas diri anak. Selain itu juga perlu diperhatikan siswa juga membutuhkan lingkungan yang mendukung pembelajaran mereka. Mereka perlu perhatian khusus dengan cara memahami cara belajarnya. Tingkat perkembangannya anak SD juga memiliki dunianya sendiri yang harus dilihat dari kacamata anak-anak. Anak SD juga menyukai permainan yang menarik dan menantang karena pada saat usia ini rasa ingin tahunya sangat besar, sehingga semua ingin dicoba. Selain itu Anak SD pada tingkat usianya selalu ingin meniru apa yang dilihatnya. Oleh sebab itu peran guru, orang tua dan lingkungan sangat penting dalam memberikan contoh yang baik dalam bersikap dan bertindak di hadapan anak-anak SD/ MI.

Disebutkan dalam Permendiknas nomor 22 tahun 2006 bahwa tujuan diberikannya pembelajaran matematika dimaksudkan agar siswa memiliki kemampuan mengkomunikasikan gagasan misalnya simbol, tabel, media lain dalam memperjelas masalah. Maka, guru berperan sebagai fasilitator yang harus dapat memilih strategi, model ataupun metode agar membantu siswa mewujudkan tujuan dimaksud (Ali, Rizal dan Lukman, 2012: 6). Di dalam kelas, khususnya pembelajaran matematika SD, proses belajar tampak kurang efektif. Guru dari awal 
pembelajaran memulai kegiatan belajar dengan doa kemudian mengabsen kehadiran siswa, dan mengajar dengan monoton. Guru hanya membaca buku paket, menjelaskan pelajaran, sedangkan siswa menulis pada buku tulis masing-masing dan saat guru menerangkan materi masih terdapat beberapa siswa kurang memperhatikan ketika dijelaskan. fakta-fakta yang dilihat saat pembelajaran tersebut pada mata pelajaran matematika. Idealnya, sebagaimana dikemukakan Suradika dkk (2019: 4-5) di kelas guru harus memiliki 11 kemampuan melaksanakan pembelajaran, yaitu (1) membuka pelajaran dengan metode yang sesuai, (2) menyajikan materi pelajaran secara sistematis, (3) menerapkan metode dan prosedur pembelajaran yang telah ditentukan, (4) mengatur kegiatan siswa di kelas, (5) menggunakan media pembelajaran/peralatan praktikum (dan bahan) yang telah ditentukan, (6) menggunakan sumber belajar yang telah dipilih (berupa buku, modul, program komputer dan sejenisnya), (7) memotivasi siswa dengan berbagai cara yang positif, (8) melakukan interaksi dengan siswa menggunakan bahasa yang komunikatif, (9) memberikan pertanyaan dan umpan balik, untuk mengetahui dan memperkuat penerimaan siswa dalam proses pembelajaran, (10) menyimpulkan pembelajaran, dan (11) menggunakan waktu secara efektif dan efisien.

Dengan memperhatikan masalah di atas, sudah seharusnya dalam proses pembelajaran matematika guru harus melakukan suatu perubahan atau inovasi dalam mengajar. Diperlukan alternatif strategi pembelajaran yang mampu membangkitan semangat, motivasi, kreatif dalam mengikuti pembelajaran. Salah satu cara yang dapat dilakukan yaitu melalui penerapan strategi pembelajaran the power of two.

The Power of Two merupakan bagian dari strategi pembelajaran aktif. Pembelajaran aktif adalah suatu pembelajaran yang mengajak peserta didik untuk belajar secara aktif. Dengan belajar aktif ini, peserta didik diajak untuk turut serta dalam semua proses pembelajaran, tidak hanya mental akan tetapi juga melibatkan fisik sehingga hasil belajar dapat dimaksimalkan (Masithah, 2016: 6).

Selain dengan menggunakan strategi pembelajaran aktif the power of two dalam menciptakan proses pembelajaran maka perlu penunjang supaya kegiatan pembelajaran dapat berjalan dengan baik dan menyenangkan yaitu dengan penggunaan media pembelajaran animasi dengan memanfaatkan aplikasi Macromedia Flash sebagai pemanfaatan untuk proses pembuatan dan pengelolaan, serta pengembangan sebagai desain pembelajaran untuk mengetahui pencapaian hasil belajar siswa.

Dengan memberikan penerapan media pembelajaran animasi dengan menggunakan Macromedia Flash dan penggunaan strategi pembelajaran aktif the power of two diharapkan pembelajaran matematika materi faktor persekutuan terbesar dan kelipatan persekutuan terkecil dengan menggunakan soal dan pembelajaran Higher Order Thinking Skills (HOTS) dapat meningkat.

\section{DEFINISI HOTS}

Menurut Thomas \& Thorne seperti dikutip Nugroho (2018:16) HOTS merupakan kemampuan berpikir yang mengharuskan seseorang melaksanakn sesuatu pada fakta 
dalam mengemukakan fakta, rumus, dan

\begin{tabular}{|c|c|c|c|}
\hline $\begin{array}{l}\text { Prob- } \\
\text { lem } \\
\text { Solv- } \\
\text { ing } \\
\text { Krulik } \\
\text { \& } \\
\text { Rud- } \\
\text { nick } \\
(1998) \\
\end{array}$ & $\begin{array}{l}\text { Tak- } \\
\text { sonomi } \\
\text { Kognitif } \\
\text { Bloom } \\
\text { Original } \\
(1956)\end{array}$ & $\begin{array}{l}\text { Tak- } \\
\text { sonomi } \\
\text { Bloom } \\
\text { Revisi } \\
\text { Ander } \\
\text { \& } \\
\text { Krath- } \\
\text { wohl } \\
(\mathbf{2 0 0 1 )}\end{array}$ & $\begin{array}{l}\text { High } \\
\text { Order } \\
\text { Think- } \\
\text { ing } \\
\text { Skills }\end{array}$ \\
\hline $\begin{array}{l}\text { Recall } \\
\text { Basic } \\
\text { (Da- } \\
\text { sar) } \\
\\
\text { Criti- } \\
\text { cal } \\
\text { Crea- } \\
\text { tive }\end{array}$ & $\begin{array}{l}\text { Knowledge } \\
\text { Compre- } \\
\text { hensive } \\
\text { Applica- } \\
\text { tion } \\
\text { Analysis } \\
\text { Synthesis } \\
\text { Evaluation }\end{array}$ & $\begin{array}{l}\text { Re- } \\
\text { mem- } \\
\text { ber } \\
\text { Under- } \\
\text { stand } \\
\text { Apply } \\
\text { Ana- } \\
\text { lyze } \\
\text { Evalu- } \\
\text { ate } \\
\text { Create }\end{array}$ & $\begin{array}{l}\text { Criti- } \\
\text { cal } \\
\text { Think- } \\
\text { ing } \\
\text { Crea- } \\
\text { tive } \\
\text { Think- } \\
\text { ing } \\
\text { Prob- } \\
\text { lem } \\
\text { Solv- } \\
\text { ing } \\
\text { Deci- } \\
\text { sion } \\
\text { Mak- } \\
\text { ing }\end{array}$ \\
\hline
\end{tabular}

prosedur. Sesuai dengan pendapat Onosko \&Newman juga dikutip oleh Nugroho (2018:16) HOTS dipahami sebagai kemampuan berpikir siswa menghubungkan pembelajaran elemen di luar potensi penggunaan pikiran dalam menghadapi tantangan yang dihadapi.

Selanjutnya Teaching Knowledge Test Cambridge English, The University of Cambridge (2015) seperti dikutip Nugroho (2018:17) menyatakan bahwa HOTS merupakan keterampilan memikirkan keputusan tentang hal untuk menyelesaikan masalah serta berpikir hal positif dan negatif dari sesuatu.

Berdasarkan uraian tersebut, dapat disimpulkan bahwa HOTS merupakan kemampuan berpikir tingkat tinggi sebagai suatu potensi dengan menggunakan pikiran dan menjadikan siswa bisa menerapkan pengetahuan dan keterampilan.
Dinni (2018:171) menyatakan bahwa tujuan dari high order thinking skills adalah meningkatkan kemampuan berpikir peserta didik di level yang lebih tinggi, berkaitan dengan kemampuan berpikir kritis untuk menerima jenis informasi dan berpikir kreatif. Konsep high order thinking skills ini didasari pada beberapa pendapat, misalnya dilihat tabel berikut:

Tabel 22 Konsep High Order Thinking Skill

Berdasarkan tabel tersebut dapat dijelaskan sebagai berikut. Bloom membagi domain kognitif menjadi enam level berpikir yaitu, (1) knowledge yaitu menggunakan pengetahuan pada situasi baru dan yang belum pernah dialami (2) comprehense yaitu menggabungkan elemen dalam membentuk keseluruhan yang baru, (3) application yaitu pengetahuan mengingat kembali infomasi, (4) analysis yaitu mengidentifikasi dan memahami bagian-bagian, (5) synthesis yaitu memahami makna materi, dan (6) Evaluation yaitu serta menilai secara hati-hati berdasarkan beberapa kriteria (Dinni, 2018: 172).

\section{LEVEL KOGNISI}

Handbook luar biasa yang mampu mengubah wajah pendidikan tersebut membagi dalam dua kategori, yaitu kategori pengetahuan dan kategori proses kognitif Kategori C: Cognitive) sampai tertinggi (C6) (Nugroho, 2018: 19).

Dilakukannya untuk menuntun focus yang disimpan rapi tapi menjadi sarana mengembalikan khitah seseorang guru sesuai dengan konteks zamannya. Selain itu, revisi dilakukan untuk menyesuaikan dengan kebutuhan yang memadukan berbagai hal baru dalam tujuan pendidikan saat ini. Beberapa hal 
praktis dalam domain kognitif telah disempurnakan oleh Anderson dan Krathwohl.

Ciri khas HOTS yaitu keterampilan siswa dalam menganalisis, mengevaluasi, dan mencipta. Indikator keterampilan menganalisis, mengevaluasi, dan menciptakan yang dipaparkan dalam revisi taksonomi Bloom.

\section{INDIKATOR KETERAMPILAN UNTUK BERPIKIR TINGKAT TINGGI (HOTS)}

Menurut KBBI, indikator mempunyaisuatu makna yang dapat memberikan (menjadi) petunjuk (Kemendiknas, 2008) dalam Anjani (2017: 25). Krathwohl dalam $A$ revision of Bloom's Taxonomy, (Aningsih 2018, 12-13) menyatakan bahwa indikator yang digunakan sebagai ciri tingkat: Menganalisis, Mengevaluasi dan Menciptakan merupakandari keterampilan berpikir tingkat tinggi. Diamati pada aspek kognitif peserta didik yaitu sebagai berikut:

\section{- MENGANALISIS}

Suatu informasi yang masuk dan membagi-bagi atau menstrukturkan informasi ke dalam bagian yang lebih kecil untuk mengenali pola atau hubungannya.

\section{- MENGEVALUASI}

Memberikan penilaian terhadap solusi, gagasan dan metodologi dengan menggunakan kriteria yang cocok atau standar yang ada untuk memastikan nilai efektivitas dan manfaatnya.

\section{- MENGKREASI (MENCIPTA)}

Membuat generalisasi suatu ide atau cara pandang terhadap sesuatu, merancang suatu cara untuk menyelesaikan masalah, serta mengorganisasikan unsur-unsur atau bagian sehingga menjadi struktur baru yang belum ada sebelumnya.
Karakteristik berpikir tingkat tinggi Menurut Resnick dalam Lewy (2009) indikator berikut ini (Anjani, 2015: 28):

1) Non algorithmic;

2) Cenderung kompleks;

3) Membutuhkan usaha untuk menemukan struktur dalam ketidakteraturan.

\section{KARAKTERISTIK SOAL HOTS}

Aningsih (2018:12-16) menyatakan terdapat tiga karakteristik soal hots, yaitu: (a) mengukur kemampuan berpikir tingkat tinggi, yaitu kemampuan memecahkan masalah, keterampilan berpikir kritis, kemampuan berargumentasi dan kemampuan mengambil keputusan, (b) berbasis permasalahan kontekstual, yakni asesmen situasi dunia nyata di kehidupan sehar-hari, supaya peserta didik menerapkan konsep-konsep pembelajaran di kelas dalam menyclesaikan masalah, dan (c) membangun bentuk soal beragam.

Berdasarkan uraian diatas dapat disimpulkan bahwa ada beberapa karakeristik pada soal-soal HOTS yang digunakan bentuk penilaian kelas misalnya berbasis permasalahan kontekstual, mengukur kemampuan berpikir tingkat tinggi siswa, membangun bentuk soal yang beragam.

\section{PEMBELAJARAN MATEMATIKA SEKOLAH DASAR}

\section{- HAKIKAT MATEMATIKA}

Matematika berasal dari bahasa Yunani "mathein" artinya "mempelajari". Diduga kata itu mempunyai hubungan dengan kata Sansekerta "medha" artinya "kepandaian", "ketahuan" (Andi Hakim Nasution seperti dikutip Karso dan Suyadi, dkk (2014: 39). Dengan kata lain matematika merupakan ilmu yang berhubungan dengan pola berpikir 
yang sudah dibuktikan kebenarannya serta membantu manusia memahami, menguasai permasalahan sosial, ekonomi, dan alam.

\section{- KARAKTERISTIK PEMBELAJA- RAN MATEMATIKA SD}

Matematika merupakan kemampuan merangkai logika berpikir bukan sekedar pandai berhitung. Dengan belajar matematika siswa diharapkan memiliki pemahaman yang benar dan lengkap sesuai dengan tahapan, cara dan media yang menyenangkan menjalankan prinsip matematika (Putri, 2017:12). Pembelajaran matematika di SD merupakan kajian penting untuk dapat memahami bagaimana membekali siswa memiliki kemampuan menghitung dan mengolah data. Pembelajaran matematika ini digunakan sebagai sarana pemecahan masalah dan mengomunikasikan ide.

Seorang guru atau calon guru di sekolah dasar harus benar-benar mengerti tentang karakteristik pembelajaran matematika di SD. Matematika sendiri merupakan ilmu yang abstrak sedangkan siswa SD yang pada umumnya berada usia 6 hingga 12 tahun masih berada pada tahapan operasional konkret. Menurut Piaget seperti dikutip Ibda (2015: 32) perkembangan psikologi berpikir anak yang berlangsung melalui empat tahap salah satunya yaitu tahapan operasional konkret yang berada pada usia 7-11/12 tahun. Pada usia tersebut atau pada tingkatan sekolah dasar di jenjang kelas IV yang berumur 10 hingga 11 tahun. Pada tahapan ini anak sudah cukup matang untuk menggunakan logika atau operasi, tetapi hanya untuk obyek fisik yang ada pada saat ini. Dalam tahapan ini pula, anak telah hilang kecenderungannya terhadap animism dan arterialise. Oleh karena itu, pembelajaran matematika tidak boleh terlepas dari hakikat matematika dan hakikat anak didik di SD.

Pembelajaran matematika di sekolah dasar berbeda dengan pembelajaran matematika SMP dan SMA. Putri (2017: 13-14) mengemukakan lima karakteristik pembelajaran matematika SD, yaitu (a) metode spiral, yaitu mengaitkian pembelajaran matematika materi yang sebelumnya, (b) dimulai dari hal yang konkret menuju hal yang abstrak, yang sedehana menuju konsep yang lebih sulit, (c) metode induktif yang menerapkan proses berpikir yang berlangsung dari kejadian khusus menuju umum, (d) menganut kebenaran secara konsistensi, artinya tidak ada pertentangan antara kebenaran yang satu dengan yang lain, dan (e) bermakna, yaitu cara pengajaran materi pembelajaran yang mengutamakan pengertian dari pada hafalan.

\section{- MATERI PELAJARAN MATEMAT- IKA KELAS IV SD}

Materi pelajaran Matematika kelas IV SD terdiri dari (a) faktor persekutuan terbesar, (b) kelipatan persekutuan, dan (c) kelipatan persekutuan terkecil dari dua bilangan berkaitan dengan kehidupan seharihari. Materi tersebut memuat sub materi sebagai berikut (a) faktor persekutuan dua bilangan (bilangan yang dapat membagi habis kedua bilangan tersebut), (b) faktor persekutuan terbesar (dua bilangan atau lebih adalah bilangan bulat terbesar yang dapat habis membagi bilangan-bilangan tersebut), dan (c) untuk menentukan fpb dapat dilakukan dengan cara menentukan semua faktor persekutuan terlebih dahulu. 


\section{STRATEGI PEMBELAJARAN AKTIF TPOT}

- DEFINISI STRATEGI PEMBELAJARAN AKTIF

Cara seorang guru melaksanakan strategi pembelajaran dalam mempengaruhi keberhasilan pencapaian kompetensi mata pelajaran. Menurut Uno dan Nurdin seperti dikutip Masruroh (2017:13) pada strategi pembelajaran diharapkan siswa terlibat langsung pada kegiatan pembelajaran berpikir, berinteraksi, menemukan konsep baru.

Siswa perlu terlibat langsung supaya tetap tertuju pada proses kegiatan belajar berlangsung sehingga dalam proses pembelajaran tersebut bukan hanya guru yang menjadi pusat pembelajaran tetapi siswa juga berperan serta dalam pembelajaran.

\section{- PRINSIP STRATEGI PEMBELAJA- RAN AKTIF}

Menurut Semiawan dan Zuharini dalam Masruroh (2017: 26), terdapat lima prinsip strategi pembelajaran, yauti (a) prinsip keterarahan fokus tertentu, (b) Keterlibatan langsung, (c) prinsip motivasi, (d) prinsip latar, dan (e) prinsip pengulangan.

\section{- KARAKTERISTIK STRATEGI PEM- BELAJARAN AKTIF}

Menurut (Masruroh, 2017: 30) karekteristik strategi pembelajaran aktif dapat dilihat dari empat segi, yaitu segi (a) peserta didik (murid), (b) pengajar (guru), (c) program pengajaran, dan (d) situasi mengajar.

\section{- STRATEGI PEMBELAJARAN THE POWER OF TWO}

Ali, Rizal dan Lukman (2012: 7) menyatakan bahwa the power of two bisa memberikan penekanan proses belajar aktif dan bekerja sama dalam meningkatkan prestasi belajar, secara berpasangan siswa diminta memecahkan masalah dalam matematika. Selanjutnya Masithah (2016: 6) menyatakan bahwa The Power of Two mempunyai istilah kekuatan dan dua. Kegiatan ini dilakukan guna meningkatkan suatu proses belajar kolaboratif, memotivasi munculnya keuntungan sinergi, sebab dua orang tentu lebih baik dari satu.

Berdasarkan uraian di atas, dapat disimpulkan bahwa kekuatan berpasangan atau berdua merupakan suatu strategi yang diminta secara berpasangan untuk memecahkan atau menyelesaikan suatu permasalahan dalam matematika supaya peserta didik aktif dapat menggunakan pemikirannya, memecahkan persoalan.

\section{- LANGKAH-LANGKAH STRATEGI PEMBELAJARAN THE POWER OF TWO}

Langkah-langkah pembelajaran kooperatif learning kekuatan berdua berdasarkan pandangan para ahli, di antaranya Sanaky (2006), Muqowin (2007), Hisyam (2008), dan Suprijono (2013) disimpulkan oleh Masithah (2014: 7) sebagai berikut:

1) Untuk guru menyajikan informasi tentang pokok-pokok materi yang dipelajari.

2) Guru membuat sepasang kelompok belajar.

3) Guru memberikan siswa menjawab soal secara personal.

4) Siswa mendiskusikan jawaban secara kelompok dan menemukan jawaban baru.

5) Guru menugaskan dan meminta pasangan kelompok membandingkan kembali jawabannya pasangan kelompok lainnya.

6) Guru melakukan kegiatan membimbing kelompok serta mempresentasikan hasil diskusi kelompok. 
7) Guru memberi klarifikasi jawaban dari masing-masing pasangan.

- KELEBIHAN DAN KEKURANGAN STRATEGI PEMBELAJARAN AKTIF THE POWER OF TWO

Menurut Mastihah (2016: 7) berikut kelebihan dan kekurangannya:

\section{KELEBIHAN}

1) Siswa aktif saat proses pembelajaran.

2) Meningkatkan tanggung jawab pada siswa.

3) Merangsang siswa agar berpikir pada hal yang sudah dipelajari.

4) Mengungkapkan idea tau gagasan sendiri maupun gagasan berdua.

5) Memberikan suatu bantuan untuk siswa belajar bekerjasama dengan orang lain.

\section{KEKURANGAN}

1) Bisa memerlukan waktu lama bila terjadi pemikiran

2) Pembagian kelompok secara berpasangan dapat membuat siswa kurang bertanggung jawab dengan tugasnya.

\section{MEDIA PEMBELAJARAN ANIMASI}

Media berasal dari bahasa Latin, yang merupakan bentuk jamak dari kata medium, yang berarti sesuatu yang terletak di tengah (antara dua pihak atau kutub) atau suatu alat. Dalam Webster Dictionary, media atau medium adalah segala sesuatu yang terletak di tengah dalam bentuk jenjang, atau alat apa saja saja yang digunakan sebagai perantara atau penghubung dua pihak atau dua hal (Sri, 2010: 4).

Media secara garis besar adalah manusia, materi, atau kejadian yang membangunkondisi yang membuat siswa mampu memperoleh pengetahuan keterampilan, atau sikap. Dalam pengertian ini, guru, buku teks, dan lingkungan sekolah merupakan media. Secara lebih khusus, pengertian media dalam proses belajar mengajar cenderung diartikan sebagai alat-alat grafis, fotografis, atau elektronis untuk menangkap memproses, dan menyusun kembali informasi visual atau verbal.

Berdasarkan uraian tersebut, dapat disimpulkan bahwa media adalah alat yang dapat membantu proses belajar mengajar dan berfungsi untuk memperjelas makna pesan yang disampaikan, sehingga dapat mencapai tujuan pembelajaran dengan baik dan sempurna.

Dalam kegiatan belajar mengajar, sering pula pemakaian kata media pembelajaran digantikan dengan istilah-istilah seperti: bahan pembelajaran (instructional material), komunikasi pandang-dengar (audio-visual communication), alat peraga pandang (visual education), alat peraga dan media penjelas.

Menurut H. Malik (1994), Media Pembelajaran adalah segala sesuatu yang dapat digunakan untuk menyalurkan pesan (bahan pembelajaran), sehingga dapat merangsang perhatian, minat, pikiran dan perasaan. Sedangkan menurut Menurut Latuheru, media pembelajaran adalah bahan, alat atau teknik yang digunakan dalam kegiatan belajar mengajar dengan maksud agar proses interaksi, komunikasi, edukasi antara guru dan siswa dapat berlangsung secara tepat guna dan berdaya (Heri, 2020).

Dalam penelitian ini media pembelajaran digunakan sebagai alat untuk pencapaian hasil belajar kemampuan berpikir tingkat tinggi siswa. Media yang digunakan yaitu 
media pembelajaran animasi. Media pembelajaran animasi menggambarkan obyek yang bergerak agar kelihatan hidup. Membuat animasi berarti menggerakkan gambar seperti, kartun, lukisan, tulisan, dan lain- lain (Sutopo, 2002: 2). Vaughan (2006: 161) juga mengemukakan animasi merupakan perubahan visual sepanjang waktu dan memberi kekuatan besar pada proyek multimedia. Animasi sudah sejak lama dikenal oleh masyarakat.

Menurut Gora (2004: 1) animasi mulai dikenal sejak populernya media televisi yang dapat menyajikan gambar bergerak hasil rekaman kegiatan makhluk hidup, manusia, atau hewan. Dibandingkan gambar foto yang diam atau tidak bergerak, televisi jelas lebih disukai karena dapat lebih membangkitkan antusiasme dan emosi penonton. Sebagai media ilmu pengetahuan animasi memiliki kemampuan untuk dapat memaparkan sesuatu yang rumit atau komplek untuk dijelaskan dengan hanya gambar dan kata-kata saja. Dengan kemampuan ini maka animasi dapat digunakan untuk menjelaskan suatu materi yang secara nyata tidak dapat terlihat oleh mata, dengan cara melakukan visualisasi maka materi yang dijelaskan dapat tergambarkan.

Penulis menggunakan media pembelajaran animasi yang digunakan yaitu media pembelajaran animasi menggunakanaplikasi Macromedia Flash. Media pembelajaran animasi berbasis aplikasi Macromedia Flash merupakan salah satu software komputer yang digunakan untuk mendesain animasi. Dengan proses pembelajaran yang menggunakan Macromedia Flash siswa tidak hanya membayangkan, tetapi siswa dapat melihat langsung konsep yang dijelaskan oleh guru. Penggunaan Macromedia Flash dalam pembelajaran dapat membantu guru dalam menjelaskan materi pelajaran dan diharapkan dapat membuat siswa lebih mudah untuk mengingat materi yang diajarkan, menjawab soal-soal latihan sebagai pemantapan pemahaman materi serta memberikan pengalaman baru untuk mebuat siswa termotivasi.

Macromedia Flash terdiri dari berbagai versi seperti Macromedia Flash 8, Macromedia Flash 5, Flash MX dan Macromedia Flash MX 2004. Macromedia Flash yang peneliti gunakan yaitu Macromedia Flash 8 dalam penggunaan media pembelajaran. Menurut kusrianto dalam Vistha (2010: 50) Macromedia Flash profesional 8 adalah software yang berisi fasilitas untuk membuat desain, media interaktif secara profesional, serta hal-hal yang berkaitan dengan sarana yang dibutuhkan untuk menyusun sebuah kontent multimedia. Selain itu, aplikasi ini juga dapat digunakan untuk membuat animasi logo, movie, game, pembuatan navigasi pada situs $w e b$, banner, tombol animasi, menu interaktif, interaktif form isian, e-card, screen saver dan pembuatan keseluruhan isi web atau pembuatan aplikasi-aplikasi web lainnya.

\section{- JENIS-JENIS MEDIA PEMBELAJA- RAN ANIMASI}

Animasi berasal dari kata "animation" yang dalam bahasa inggris "to animate" yang berarti menggerakkan. Tenik pembuatan animasi dapat dilihat menajadi 3 kategori yaitu, (a) stop-motion animation yaitu jenis animasi yag masih menggunakan tanah liat sebagai obyek yang digerakkan, (b) animasi 
tradisional yaitu media yang pertamakali dikembangkan, dengan perkembangan teknolgi media ini telah dikerjakan dengan komputer dan dikenal sebagai media dua dimensi, (c) animasi komputer adalah animasi yang secara keseluruhan dibuat atau dikerjakan dengan komputer, dari pembuatan karakter, mengatur gerakan, pemberian suara, dan memberikan effeknya dikerjakan dengan komputer.

Dalam penggunaan media pembelajaran animasi kategori teknik pembuatan animasi yaitu dengan animasi komputer di mana penggunaan media pembelajaran dengan basic teknologi atau komputer memberikan dampak yang positif bagi kemampuan dan kemauan siswa untuk mengikuti proses pembelajaran.

\section{- PEMBuAtan media PEMBela- JARAN ANIMASI}

Pembuatan media animasi dimulai dari mengumpulkan bahan untuk membuat media seperti materi yang akan disampaikan. Instal software tertentu untuk membuat animasi pada komputer. Buatlah gambar pola pada aplikasi tersebut dengan tool yang ada pada program. Import gambar hingga masuk ke dalam lembar kerja, sesuaikan gambar dengan lembar kerja. Kunci layer dengan klik tombol lock, kemudian buatlah layer baru. Masukkan pola pada timeline dan tentukan waktu pada layer, gerakkan dengan create motion tween. Membuat media animasi pada komputer dengan membuat beberapa scene dengan ukuran 1024 x 720 px, kemudian memasukkan materi pada layer timeline, buat pola pada komputer. Buat media sesuai dengan naskah yang telah di buat. Media animasi ini terdiri dari 6 scene. Untuk melihat atau mengecek dengan cara control-enter pada keyboard secara bersamaan. Setelah media tersebut selesai dibuat kemudian di eksport dengan file $(. s w f)$.

Proses pembelajaran pada pembelajaran matematika kelas IV Sekolah Dasar berbasis HOTS (Higher Order Thinking Skills) dilakukan dengan menggunkan media pembelajaran animasi berbasis Macromedia Flash pada materi FPB dan KPK. Berikut ini adalah langkah-langkah pembelajaran pada kelompok eksperimen yang dilaksanakan di kelas IV Sekolah Dasar pada pokok bahasan FPB dan KPK berbasis HOTS.

\section{PERTEMUAN PERTAMA}

Pada kelas IV Sekolah Dasar, pembuat menjelaskan materi sesuai dengan Rencana Pembelajaran dengan menggunakan buku paket matematika Kelas IV Sekolah Dasar. Kemudian menyimpulkan materi yang telah diajarkan dan menugaskan peserta didik untuk mempelajari materi yang diajarkan dengan menggunakan buku paket matematika kelas IV bahasan FPB dan KPK.

\section{PERTEMUAN KEDUA}

Dalam tahap ini, sebelum proses pembelajaran pada pokok bahasan FPB dan KPK dimulai, sebagai langkah awal pembelajaran, maka dilakukan pretest terlebih dahulu dengan tujuan untuk mengetahui hasil belajar peserta didik, sebelum menerima pokok bahasan Matematika kelas IV sekolah dasar dengan jumlah soal 5. Tahapan berikutnya adalah peserta didik menerima materi pokok FPB dan KPK berbasis HOTS kelas sepuluh dengan media pembelajaran animasi berbasis Macromedia Flash pada materi FPB dan KPK yang dijelaskan oleh peneliti. 


\section{PERTEMUAN KETIGA}

Setelah melaksanakan kegiatan pembelajaran dengan menggunakan media pembelajaran pada pokok bahasan FPB dan KPK tahapan berikutnya adalah pembuat melakukan posttest untuk mengetahui hasil belajar peserta didik setelah melakukan pembelajaran dengan menggunakan media pembelajaran dengan jumlah soal 10 sebagai keberhasilan dalam penerapan media pembelajaran animasi berbasis Macromedia Flash.

\section{LANGKAH-LANGKAH PENERAPAN MEDIA PEMBELAJARAN ANIMASI DALAM PROSES PEMBELAJARAN}

1) Melakukan kegiatan apresiasi sesuai dengan kegiatan yang terdapat pada RPP yang telah dibuat.

2) Membuka pembelajaran dengan tanya jawab kepada siswa, kemudian menjelaskan materi bahasan FBP dan KPK berbasis HOTS sesuai dengan tujuan pembelajaran yang terdapat pada RPP yang telah dibuat.

3) Peneliti mulai menggunakan media pembelajaran animasi supaya siswa dapat bersemangat dalam belajar.

4) Tahap terakhir peneliti melakukan evaluasi terhadap ketercapaian hasil belajar siswa menggunakan media pembelajaran online.

\section{KEKURANGAN DAN KELEBIHAN ME- DIA PEMBELAJARAN ANIMASI}

Jenis media yang dimanfaatkan dalam proses pembelajaran cukup beragam Media pembelajaran menurut kustandi sebagaimana dikutip oleh Dwi (2016: 30) mempunyai kekurangan dan kelebihan.
Kelebihan menggunakan obyek bergerak seperti film, video dan bantuan komputer sebagai media belajar adalah sebagai berikut:

1) Media film dan video dapat melengkapi pengalaman-pengalaman dasar siswa ketika mereka membaca, berdiskusi, praktik, dll.

2) Menggambarkan suatu proses secara tepat dan dapat disaksikan secara berulang jika diperlukan.

3) Menanamkan sikap dan segi afektif, mendorong dan meningkatkan motivasi.

4) Menyakilan peristiwa kedalam kelompok besar atau kelompok kecil.

5) Kemampuan teknik mengambil gambar frame demi frame, peristiwa yang dalam kecepatan normal memakan waktu satu minggu dapat ditampilkan beberapa menit. Media dengan komputer dapat berhubungan dan mengendalikan peralatan lain, seperti compact disc, video tape, dan lain-lain, dengan program pengendali dari komputer.

Kekurangan menggunakan obyek bergerak seperti film, video dan bantuan komputer sebagai media belajar adalah sebagai berikut:

1) Pengadaan film dan video memerlukan biaya mahal dan waktu yang banyak.

2) Menggunakan komputer memerlukan keterampilan dan pengetahuan khusus tentang komputer.

3) Keragaman model komputer (hardware) sering menyebabkan program (software) yang tersedia tidak cocok dengan model yang lainnya.

4) Komputer efektif jika digunakan oleh salah satu orang atau beberapa orang dalam kelompok kecil. 


\section{KESIMPULAN}

Dari pembahasan yang sudah diuraikan pada bagian sebelumnya dapat disimpulan sebagai berikut:

1) Dengan tingkat kemampuan berpikir tingkat tinggi siswa yang masih rendah maka diperlukannya beberapa soal-soal latihan berbasis HOTS yang memicu tingkat berpikir siswa yang diberikan oleh guru.

2) Guru harus dapat mendesain sebuah pembelajaran yang aktif dan menyenangkan sehingga siswa tidak merasa bosan dalam pembelajaran.

3) Dalam mendukung tercapainya program pembelajaran maka diperlukan strategi pembelajaran yang aktif dan menyenangkan yaitu salah satunya yang penulis gunakan menggunakan strategi The Power of Two.

4) Selain itu juga didukung oleh media pembelajaran yang menarik yang di desain semaksimal mungkin agat siswa dapat tertatik sehingga pesan pembelajaran dapat tersampaikan dengan baik. Salah satunya yaitu menggunakan media animasi dengan berbasis Macromedia Flash.

5) Dalam strategi pembelajaran aktif dan media pembelajaran animasi yang didesain memiliki kelebihan dan kekurangannya. Diperlukan kemampuan untuk menyesuaikan dan mengaplikasikannya berdasarkan pada kebutuhan siswa.

\section{REFERENSI}

Ali, Jumalia, Yusmet Rizal dan Nurhayati Lukman. 2012. Strategi Pembelajaran Aktif The Power Of Two dan Kemampuan Komunikasi Matematika. Jurnal Pendidikan Matematika, Part 2, 1 (1): 16. (http://ejournal.unp.ac.id/students/ind ex.php/pmat/article/view/1146, diakses pada 17 februari 2019).

Anjani.2017. Analisis Kemampuan Berpikir Tingkat Tinggi Menurut Teori Anderson dan Krothwohl Pada Peserta Didik Kelas XI Bilingual Class System MAN 2 Kudus Pada Pokok Bahasan Linier.Skripsi diajukan untuk memenuhi sebagian syarat memperoleh gelar sarjana pendidikan Pendidikan Matematika Universitas Islam Negeri Walisongo. (http://eprints.walisongo.ac.id/7826/, diakses pada tanggal 25 februari 2019).

Aningsih, Anugrah. 2018. Kemampuan Berpikir Tingkat Tinggi pada Pendidikan Agama Islam Siswa Kelas X SMK Muhammadiyah 1 Purwokerto Ditinjau dari Prestasi Belajar.Skripsi Program Sarjana Ilmu Pendidikan.Universitas Muhammadiyah Purwokerto. Diakses dari:

http://repository.ump.ac.id/7373/3/An ugrah $\% 20$ Aningsih $\% 20 \mathrm{Bab} \% 20$ II.pd f pada tanggal 12 November 2018).

Dinni, Nur Husna. 2018. HOTS (High Order Thinking Skills) Dan Kaitannya Dengan Kemampuan Literasi Matematika. PRISMA PROSIDING SEMINAR NASIONAL MATEMATIKA.(https://journal.unnes .ac.id/sju/index.php/prisma/, diakses pada tanggal 7 November 2018).

Feny Mega, Vistha. 2010. "Pengembangan Media Pembelajaran Geometri Ruang Berbasis Multimedia Pada Materi Bangun Ruang Sisi Datar Untuk Siswa Smp Kelas VIII". Skripsi. Yogyakarta: Fakultas Matematika dan Ilmu Pengetahuan alam, Universitas Negeri Yogyakarta

Hamiyah, Nur dan Muhamad Jauhar. 2014. Strategi Belajar Mengajar di Kelas. Prestasi Pustaka: Jakarta.

Heri. 2020. MEDIA PEMBELAJARAN: Pengertian, Fungsi, Manfaat, Jenis Jenis \& Contoh. (diakses melalui: https://salamadian.com/pengertianmedia-pembelajaran/) 
Ibda, Fatimah. 2015. Perkembangan kognitif: Teori Jean Piaget. Jurnal Penelitian Dosen Fakultas Tarbiyah dan Keguruan UIN Ar-Raniry, 2 (1). (https:// jurnal.Ar-raniry.ac.id

Karso, M.H dan Gimin Suyadi dkk. 2014. Pendidikan Matematika 1. Tangerang Selatan: Universitas Terbuka.

Kurniati, Dian, Romi Harimukti dan Nur Asiyah Jamil. 2016. Kemampuan Berpikir Tingkat Tinggi Siswa SMP di Kabupaten Jember dalam menyelesaikan soal berstandar PISA. Jurnal Penelitian dan Evaluasi Pendidikan 20 (2) Desember 2016 (142-155).

(http://Journal.uny.ac.id/index.php/ip ep)

Lesmana, Adi Dimas. 2016. Indentifikasi Profil Kemampuan Berpikir Tingkat Tinggi Siswa SMA Menggunakan Instrumen Two-Tier Test Pada Mata Pelajaran Fisika. Skripsi sebagai syarat untuk memperoleh Gelar Sarjana Pendidikan (S.Pd) Program Studi Pendidikan Fisika Universitas Islam Negeri Syarif Hidayutulah Jakarta.

(http://repository.uinjkt.ac.id/dspace/ bitstream/123456789/31777/3/DIMA S\%20ADI\%20LESMANA_FITK.pdf )

Maolani, A. Rukaesih. 2015. Metodologi Penelitian Pendidikan. PT. Raja Grafindo Persada: Jakarta.

Masithah, Ita. 2016. Pengaruh Model Pembelajaran Kooperatif Tipe ThePower of Two (Kekuatan Berdua) Terhadap Kemampuan Berpikir Kritis Siswa SMPN 11 Mataram Pada Mata Pelajaran IPA Tahun Ajaran 2016/2017.Artikel Penelitian Program Studi Pendidikan Biologi Universitas Mataram. (https://www.google.com/url?sa=t\&s ource $=$ web\&rct $=\mathrm{j} \&$ url $=$ https://anzdoc .com/download/artikel-penelitianoleh-itha-masithah)

Masruroh, Umi. 2017. Implementasi Strategi Pembelajaran Aktif (Active Learning)
Dalam Pembelajaran Tematik Di MIN

Kauman Utara Jombang.Skripsi Program Studi Pendidikan Guru Madrasah Ibtidaiyah Universitas Islam Negeri Maulana Malik Ibrahim Malang.

(https://www.google.com/url?sa=t\&s ource=web\&rct=j\&url=http://etheses. uin-

malang.ac.id/6907/1/12140064.pdf\& ved=2ahUKEwi2jabPyubhAhVEvo8 KHctkBWwQFjAAegQIAxAB\&usg =AOvVaw21IhAuAYaykBFbR00$\underline{\mathrm{R} 7 \mathrm{n} 5}$

Masykur, Rubhan, Nofrizal dan Muhamad Syazali. 2017. Pengembangan Media Pembelajaran Matematika dengan Macromedia Flash. Al-Jabar: Jurnal Pendidikan Matematika Vol. 8, No. 2, 2017, Hal 177 - 186.

Nugroho, R. Arifin. 2018. HOTS (Higher Order Thinking Skills). Jakarta: PT Gramedia Widiasarana Indonesia.

Nurhayati dan Lia Anggraeni. 2017. Analisis Kemampuan Berpikir Tingkat Tinggi Mahasiswa (Higher Order Thinking) dalam Menyelesaikan Soal Konsep Optik melalui Model Problem Based Learning.Jurnal Penelitian \& Pengembangan Pendidikan Fisika 3 (2):120. (http://doi.org/10.21009/1)

Sanjaya, Wina H. 2006. Strategi Pembelajaran Berorientasi Standar Proses Pendidikan. Kencana: Jakarta.

Shadiq, Fadjar. 2014. Pembelajaran Matematika; Cara Meningkatkan Kemampuan Berpikir Siswa.Graha Ilmu: Yogyakarta.

Suparmin, Aditya Nur Rochma dkk. 2016. Buku Guru Matematika Untuk SD/MI Kelas IV. Surakarta: CV Mediatama.

Suradika S, D Wicaksono, W Winata. (2019). Workshop Penyusunan RPP Kurikulum 2013 Revisi Bagi GuruGuru Sekolah Dasar Di Kabupaten Malang. Prosiding Seminar Nasional Pengabdian Masyarakat LPPM UMJ. (https://jurnal.umj.ac.id/index.php/se mnaskat/article/view/5375) 